Prace Literackie LVII

Wrocław 2017

DOI: $10.19195 / 0079-4767.57 .7$

\author{
ARKADIUSZ SYLWESTER MASTALSKI \\ Prywatne Akademickie Centrum Kształcenia \\ Pracownia Poetyki Wiersza Uniwersytetu Warszawskiego
}

\title{
Wiersze z Google — problemy autorstwa i sprawczości w świetle teorii wiersza
}

\section{Wiersze w Sieci}

Mówiąc o wierszach w Sieci ${ }^{1}$, można mieć na myśli bądź to utwory poetyckie w tradycyjnym tego słowa znaczeniu (,analogowe”) - sfotografowane, przepisane czy zeskanowane lub w inny sposób zamieszczone na stronie internetowej, portalu poetyckim albo „w chmurze" (na przykład Dropbox czy Google Drive) $)^{2}$, bądź też projekty poetyckie stworzone specjalnie po to, by istnieć w ,webowej" rzeczywistości. Wśród tych drugich wyróżnić możemy wszelkiej maści wytwory poetyki re-writingu, gdzie teksty źródłowe przynależące do domeny słowa-druku zaadaptowane zostają do istnienia w nowych mediach lub za pośrednictwem tychże zyskują swój nowy kształt. Mówiąc natomiast o re-writingu, czyli prze-pisywaniu, mam tutaj na myśli oczywiście nie mechaniczny akt kopiowania, lecz raczej pewien artystyczny gest ${ }^{3}$; to, co opisują Agnieszka Izdebska i Danuta Szajnert we wstępie do monografii Literatura prze-pisana, mówiąc o ,szczególnej postaci literackiego, i nie tylko literackiego, recyklingu - czytania/interpretowania/pisania od nowa [...] tego, co już zostało napisane"4. Według badaczek najistotniejszą cechą literatury „prze-pisanej” jest aktywizowanie punktowych odniesień do innych, cudzych wypowiedzi; semantycznej i ideologicznej rewa-

${ }^{1}$ Por. pionierskie na gruncie polskim opracowanie W. Sadowskiego, Wiersz w sieci, [w:] Tekst (w) sieci. Literatura, społeczeństwo, komunikacja, t. 2, red. A. Gumkowska, Warszawa 2009.

2 Por. M. Maryl, F5: Odświeżanie filologii, „Teksty Drugie” 2014, nr 2, s. 10.

3 Przykładowo Leszka Onaka zapis remiksu sonetu Mickiewicza - idem, Kroki Akermańskie, [w:] L. Onak, Ł. Podgórni, wgraa, Kraków/Internet 2012, s. 20. Por. Z. Guty, Sonet jako aplikacja internetowa. Twórcza kontynuacja czy degradacja gatunku?, [w:] Nowe media w języku, literaturze i kulturze, red. K. Sakowski, L.M. Plęs, Łódź 2016, s. 97-99.

${ }^{4}$ A. Izdebska, D. Szajnert, Wstęp, [w:] Literatura prze-pisana. Od Hamleta do slashu, red. A. Izdebska, D. Szajnert, Łódź 2015, s. 7. 
loryzacji poddawane są w niej fragmenty lub większe całości tychże, wykonana zaś przez kopistę (nie autora, lecz raczej skryptora) kopia ma charakter twórczy, stanowi rezultat „twórczego czytania"

Problem literatury prze-pisanej to oczywiście niepomiernie bardziej rozległe i złożone zjawisko ${ }^{6}$, daleko wykraczające poza problematykę wersyfikacyjną. Sądzę jednak, że wskazanie na prozodyjne praktyki re-writingu ma znaczenie niebagatelne, albowiem (o czym warto pamiętać) prozodia, niezależnie od jej charakteru (prozodia mowy, zapisu itd. ${ }^{7}$ ), jest niezbywalnym składnikiem komunikacji werbalnej. Mówiąc o wersyfikacyjnych praktykach re-writingowych w przestrzeni Internetu, nie mam na myśli szerszego i bogatszego zjawiska, jakiem jest e-poezja $\mathrm{w}$ ogóle ${ }^{8}$, lecz jedynie wybrane, dotyczące ars versificandi, zjawiska, z jakimi mamy do czynienia jako czytelnicy, kiedy czytamy wiersze w Sieci (czyli to, co ma związek z poetycką prozodią) $)^{9}$.

Samo przepisanie, choć może mieć formę, która jest rzeczywiście dokładną, dosłowną kopią innego tekstu, stanowi rodzaj „twórczego pasożytowania” hipertekstu na materiale hipotekstu. Do bardziej zachowawczych przykładów re-writingu (przepisywania, pisania-od-nowa) należą choćby animacje typografii kinetycznej, parodie, pastisze, thumaczenia czy adaptacje. Zdecydowanie dalej idą eksperymenty takie, jak zamieszczony w czwartym numerze internetowego „Nośnika”, wydawanego nakładem Rozdzielczości Chleba — która, przypomnijmy, podejmuje tematykę szeroko rozumianej poezji cybernetycznej, kultury cyfrowej i tym podobnych — klasyczny już wiersz Marcina Świetlickiego Pod wulkanem, skompilowany przez Leszka Onaka w dialogu, w którym poeta rozmawia z Wirtualnym Doradcą ZUS — oto fragment:

\section{[UŻYTKOWNIK:]}

Wszystkie dokumenty uległy rozkładowi.

[WIRTUALNY DORADCA:]

Przy zawieraniu umowy $\mathrm{z}$ otwartym funduszem emerytalnym ubezpieczony powinien przekazać agentowi ubezpieczeniowemu swoje dane identyfikacyjne, tj. imię i nazwisko, datę urodzenia

\section{Ibidem.}

${ }^{6}$ Por. C. Maisonnat, J. Paccaud-Huguet, A. Ramel, Introduction, [w:] Rewriting/Reprising in Literature: The Paradoxes of Intertextuality, red. C. Maisonnat, J. Paccaud-Huguet, A. Ramel, Cambridge, MA 2009, s. vii-Xxiii.

7 W. Sadowski, Prozodia zapisu, [w:] idem, Wiersz wolny jako tekst graficzny, Kraków 2004, s. $215 \mathrm{n}$.

8 Zob. M.G. Kirchenbaum, Electronic Poetry, [w:] The Princeton Encyclopedia of Poetry and Poetics, wyd. 4, red. R. Greene et al., Princeton, NJ 2012, s. 394-397.

9 Świadomie (również ze względu na ograniczony format publikacji w czasopiśmie naukowym) nie odnoszę się tutaj szerzej do zjawiska cyberpoezji, uznając, że celem omówienia nie jest pokazanie relacji pomiędzy wierszami poetów cybernetycznych i wierszami z Google, ale jedynie próba charakterystyki tych drugich. Por. A. Świeściak, Awangardowa cyberpoezja?, „Postscriptum Polonistyczne" 2014, nr 2 (14); U. Pawlicka, (Polska) poezja cybernetyczna. Konteksty i charakterystyka, Kraków 2012, i inne. 
oraz PESEL i NIP — a jeżeli ubezpieczonemu nie nadano tych numerów lub jednego z nich — serię i numer dowodu osobistego lub paszportu ${ }^{10}$,

czy też wydany w 2015 r. w thumaczeniu automatycznym Ubu Król Alfreda Jarry'ego $^{11}$, którego powstanie nadzorowali Aleksandra Małecka i Piotr Marecki (choć akurat ten tekst niejako powraca do kultury typograficznej za pośrednictwem druku). Książka ta łączy w sobie elementy literatury cyfrowej i analogowej. Dzięki wykorzystaniu strategii re-writingu powraca do kanonicznego już dramatu Jarry'ego z roku 1888, by na nowo odczytać go w innej, jednocześnie post-typograficznej i — jak się okaże — post-ludzkiej perspektywie programu komputerowego.

\section{Niekreatywość a zagadnienie autorstwa}

Nienowa zgoła idea kolejnego w dziejach danej literatury przekładu tekstu należącego do kanonu łączy się tu z ideą transgresji, bo tłumacz nie ma cielesnej osoby, ale funkcjonuje jako suma doświadczeń językowych użytkowników Sieci, efekt ich interakcji z nią (statistical machine translation) ${ }^{12}$. Jest więc nie tylko czymś na kształt literackiego eksperymentu, ale również dialogu z oryginałem, jaki odbywa się w przestrzeni translacji (a jednocześnie w przestrzeni nowych technologii i aktualnych strategii uczestnictwa w kulturze), o którym Marecki mówi: „Ubu Król to farsa rodem z gimnazjum wymierzona w nielubianego nauczyciela i jednocześnie próba stworzenia teatru bez teatru. Na tej zasadzie chcieliśmy zrobić tłumaczenie bez tłumaczenia", Małecka zaś dodaje:

Google Translate filtruje zbiorową świadomość. Posługuje się bazą danych, jaką jest Internet, czerpiąc z thumaczeń, które w niej znajduje. Zatem tak naprawdę to, co otrzymujemy, jest sumą przekładów wielu ludzkich tłumaczy, którzy włożyli pracę w różnego typu teksty. Wyniki tłumaczeń oparte są na statystyce ${ }^{13}$.

Autorzy sięgają po strategię niekreatywnego pisania, po (pozytywnie pojmowaną) nieoryginalność ${ }^{14}$; pokazują przenikanie się rzeczywistości humanistycznej i tego, co poza nią ${ }^{15}$; sięgają po algorytmiczno-statystyczną implementację

10 L. Onak, Marcin Świetlicki rozmawia z Monika, Wirtualnym Doradca ZUS, „Nośnik” nr 4: ZUS 2016, 1 (4), s. 64-66, http://ść-ch.pl/marcin-swietlicki-rozmawia-z-monika-wirtualnym-doradca-zus/ [dostęp: 12.07.2016].

11 A. Jarry, Ubu Król, spolszczyli przez thum. automatyczne A. Małecka, P. Marecki, Kraków 2015; por. Rozmowa redakcyjna o nowym przektadzie „,Ubu Króla”, „Ha!art” nr 50, 2/2015.

12 Zob. https://en.wikipedia.org/wiki/Google_Translate\#cite_note-44 [dostęp: 22.07.2016].

13 Oba wyimki z cytowanej rozmowy.

14 Ibidem. Zob. też: K. Goldsmith, Uncreative Writing: Managing Language in the Digital Age, New York 2011.

15 Por. L. Manovich, Język nowych mediów, przeł. P. Cypryański, Warszawa 2006, s. 115, cyt. za: M. Filiciak, Tekst jako plik. Techno-spoleczne wymiary czytania na przyktadzie przemian procesów dystrybucji tekstów akademickich, „Teksty Drugie” 2012, nr 6, s. 258. Na medializację systemu 
tego, co z dnia na dzień „,wydarza się” w polskiej netosferze. Teatr absurdu realizujący się za sprawą bohaterów i akcji, ale też w samym języku, staje się w najnowszym tłumaczeniu również absurdem samego tłumaczenia. Ubu nie jest już efektem pracy autora i translatora, lecz wynikiem współpracy twórcy tekstu źródłowego, redaktorów, aplikacji oraz milionów Polaków, którzy korzystają z Sieci. Zmienia się zatem także rozumienie pojęcia sprawczości w procesie komunikacji literackiej, to znaczy przestaje być ona jedynie cechą aktywności ludzi, gdyż angażuje zarówno ich działania, jak i działania innych podmiotów (komputerów) ${ }^{16}$, co oznacza również, że Małecka i Marecki przeceniają (przynajmniej deklaratywnie) swą rolę w procesie powstawania hipertekstu.

To ważne: techniki pisania wykorzystujące Sieć, aplikacje, repozytoria itp. mają ponadjednostkowy charakter nie tylko ze względu na słownik (zasoby), ale również gramatykę, bo język nie należy do nikogo z osobna, a raczej do wszystkich naraz, jest wypadkową tego, co w Internecie rzeczywiście, w sensie komunikacyjnym, się dzieje. Jeśli w wyniku tekstotwórczych operacji powstaje coś nowego, nie jest ono w istocie nowe sensu stricto, ale tylko znalezione - stąd stosowane czasem określenie found poetry będące literackim odpowiednikiem objet trouvé. Oczywiście nie wszystkie teksty re-writingowe są w istocie przedmiotami gotowymi — bo jednak w przeważającej liczbie przypadków poddaje się je jakimś zabiegom transformacyjnym — niemniej o ich istocie przesądzają dwa czynniki: 1. bierność podmiotu twórczego, którego gest ogranicza się do użycia czegoś, co istniało uprzednio, oraz 2. samo uprzednie istnienie zasobu, który (niczym przedmiot gotowy Duchampa) będąc nieswoistym i powszechnym, jest jedynie ,podnoszony z ziemi” (wyszukiwany na serwerze) po to, by stać się przedmiotem sztuki.

W nowym przekładzie Króla Ubu program komputerowy staje się współtłumaczem (współautorem?) dzieła ${ }^{17}$. Podobnie w projekcie Onaka - tu ZUS-owski cleverbot to, na równi ze Świetlickim, podmiot konwersacji, ale też ,aktor” w scence, której autor Kroków Akermańskich jest jedynie organizatorem. Co więcej, oboje (bot i poeta) są w swoich poczynaniach zdeterminowani przez algorytmy. Wirtualnego Doradcę determinuje algorytm programu komputerowego, natomiast Świetlickiego swoisty ,algorytm” wiersza, za sprawą którego może mówić tylko to, co już wcześniej zostało wypowiedziane w tekście poetyckim. Ta uprzedniość jest zarówno cechą materiału (na przykład wiersza Świetlickiego, dramatu Jarry’ego), jak i strategii generującej tekst, albowiem tak wprowadzenie

społecznego zwraca z kolei uwagę A. Hejmej, Literatura w społeczeństwie medialnym, „Teksty Drugie" 2014, nr 2, s. 241.

16 Por. A. Kil, Nowe media jako nasi wspólnicy: o sprawczości technologii na podstawie myśli Bruno Latoura, „Teksty Drugie” 2012, nr 6, s. 371.

17 Zob. Od wydawcy, [w:] A. Jarry, op. cit., s. 5-6. Por. A. Legeżyńska, Ttumacz jako drugi autor - dziś, [w:] Przektad literacki. Teoria - historia - wspótczesność, red. A. Nowicka-Jeżowa, D. Knysz-Tomaszewska, Warszawa 1997, s. 49. 
fraz zaczerpniętych z poezji autora Schizmy do internetowego narzędzia komunikacyjnego ZUS, jak wrzucenie tekstu francuskiego twórcy do translatora ogranicza się w zasadzie do mechanicznej czynności kopiowania-wklejania. Niemniej jest to jednocześnie operacja sensotwórcza i jej efekt w przypadku pracy Onaka możemy interpretować jako egzemplifikację komunikacyjnych aporii dialogu pomiędzy człowiekiem i AI, ale także jako swoisty komentarz, jaki współczesna kultura i cywilizacja dodają do topicznej u krakowskiego poety figury outsidera, o którym „niczego nie ma w konstytucji” ${ }^{18}$.

Na pozór możemy odnieść wrażenie, że teksty takie, jak Marcin Świetlicki... Onaka czy automatyczny przekład sztuki Alfreda Jarry'ego (i im podobne), niewiele się różnią od wierszy Stanisława Barańczaka, gdzie przetworzeniu ulega język „znaleziony”, poetyckiego recyklingu własnej (i cudzej) twórczości w wierszach Tadeusza Różewicza ${ }^{19}$ (czy innych). Jest to jednak podobieństwo pozorne. Omówione przeze mnie pokrótce przykłady jasno bowiem pokazują, jak kategoria autora jako odrębnej „siły sprawczej” dramatu czy wiersza ustępuje rozmaitym niezależnym siłom (aktorom - według Brunona Latoura ${ }^{20}$ ), za sprawą jakich kształtowany jest tekst.

\section{Czym są Wiersze z Google?}

Przykładem podobnej strategii tworzenia poezji „,znalezionej” czy niekreatywnego pisania wierszy są tzw. Wiersze z Google istniejące jako strona internetowa $^{21}$ i profil na Facebooku ${ }^{22}$, które stanowią część szerszego zjawiska, jakim jest istnienie profilów o tematyce literackiej w ramach mediów społecznościowych. Polskie Google Poems to efekt wysiłku grupowego, spontanicznej kreatywności internautów (choć pomysłodawcami „spolszczenia” tego typu twórczości i autorami strony są dziennikarze Joanna Sosnowska i Piotr Gnyp) ${ }^{23}$.

Jeśli wierzyć informacji zamieszczonej na stronie anglojęzycznego serwisu publikującego owe teksty, ich powstanie należałoby datować na rok 2012, a zmierzch zainteresowania nimi na $2015^{24}$. Polski odpowiednik serwisu powstał w lipcu 2013 r. i w momencie, gdy piszę te słowa, wciąż jest aktywny — na Facebooku, nie zaś na stronie, gdzie ostatni wpis pochodzi z roku 2015. Google

18 Por. M. Świetlicki, Pod wulkanem, [w:] idem, Wiersze, Kraków 2011, s. 126.

19 Por. T. Kunz, „Próba nowej całości”. Tadeusza Różewicza poetyka totalna, „Przestrzenie Teorii" 2006, nr 6, s. 130-132.

20 Zob. omówienie w pracy: K. Arbiszewski, Teoria Aktora-Sieci Bruno Latoura, „Teksty Drugie" 2007, nr 1-2.

21 http://wierszezGoogle.tumblr.com/ [dostęp: 25.12.2016].

$22 \mathrm{https} / /$ www.facebook.com/WierszeZGoogle/about/ [dostęp: 21.12.2016].

23 Zob. J. Sosnowska, ,, Wiersze z Google”, czyli jak trafić do galerii sztuki współczesnej (2014), http://kobieta.gazeta.pl/kobieta_ekstra/1,155242,15858206 [dostęp: 18.05.2014].

$24 \mathrm{http} / / / w w w . G o o g l e p o e t i c s . c o m /[$ dostęp: 25.12.2016]. 
Trends podaje, że szczyt popularności Wierszy z Google obrazowany na podstawie liczby wyszukań przypada na lipiec 2013 r., po którym to czasie zainteresowanie serwisem spada. Podobne wnioski można wysnuć z analizy archiwum strony, gdzie widać, że największa liczba publikacji przypada na okres od lipca do września tegoż roku ${ }^{25}$.

Oto jak wiersze opisuje Sosnowska:

Oczywiście, sam pomysł na wiersze generowane przez Google nie był nowy. W anglojęzycznym internecie znany jest Google Poetics, a my stworzyliśmy jego polski odpowiednik. Zasada działania jest banalnie prosta — znacie pewnie mechanizm autouzupełniania w Google. Zaczynacie wpisywać jakąś frazę, a wyszukiwarka sama podpowiada, co jej zdaniem może nas zainteresować. Przypatrzcie się, co powstaje w Google przed naciśnięciem „Enter”. Wyniki są czasem zabawne, czasem straszne, a czasem po prostu liryczne. A co więcej - autouzupełnianie „uczy się” i dopasowuje do najpopularniejszych wyszukań. [...]

Niektóre wiersze do dziś mnie zachwycają. Zostały wygenerowane przez algorytm, ale i tak bywają wśród nich naprawdę poruszające i liryczne ${ }^{26}$.

Gdyby więc pokusić się o wstępne sformułowanie najprostszej definicji wierszy z Google, mogłaby ona brzmieć następująco: są to krótkie utwory powstałe w oparciu o wyniki wyszukiwania wygenerowane jako podpowiedzi uzyskane dla wybranej frazy z pomocą wyszukiwarki internetowej Google, których kształt (w tym również organizacja prozodyjna) jest zdeterminowany przez sposób ich przedstawienia w wyszukiwarce, nie zaś w wyniku celowej aktywności wyszukującego. Zaznaczyć trzeba w tym miejscu, że termin „wiersz” funkcjonuje w tej definicji przede wszystkim w znaczeniu „krótki tekst poetycki" (ang. poem), a dopiero wtórnie denotuje wersyfikacyjny charakter tych utworów (do czego wrócę później). Co więcej, tego rodzaju szkicowa definicja to, rzecz jasna, jedynie punkt wyjścia, ma ona bowiem — jak się wkrótce przekonamy - charakter de facto powierzchowny i nie pozwala uchwycić istoty tego rodzaju tekstów, a jedynie ich ,generatywną" poetykę, tj. proces powstawania utworu krok po kroku widziany z perspektywy użytkownika wyszukiwarki. A wygląda on mniej więcej tak: by stworzyć wiersz z Google, należy w oknie wyszukiwarki wpisać jakiś ciąg literowy mogący mieć postać zarówno pełnego wyrazu semantycznego, jak i wyrazu synsemantycznego lub innego, w zasadzie dowolnego, zestawu znaków. Zanim klikniemy „wyszukaj”, w oknie wyszukiwarki pojawia się kilka podpowiedzi (przeważnie cztery, ale nie jest to regułą), które wystarczy spisać bądź zapisać w formie zrzutu ekranu. W efekcie uzyskujemy na przykład taki wynik, jak zamieszczony niżej, gdzie hasło wyszukiwania w postaci wyrazu (czasownika) „płonął” - nazwijmy go, jako przedstawiciela kategorii, bo może to być równie dobrze fragment leksemu, jeden wyraz czy jakaś większa całostka

\footnotetext{
$25 \mathrm{http}: / /$ wierszezGoogle.tumblr.com/archive [dostęp: 19.12.2016].

26 J. Sosnowska, op. cit. [pisownia oryginalna - ASM].
} 
składniowa, frazą generującą — daje wynik w postaci czterowiersza opartego na anaforze (która jest w wierszach z Google częsta, niemniej nie jest regułą) ${ }^{27}$.

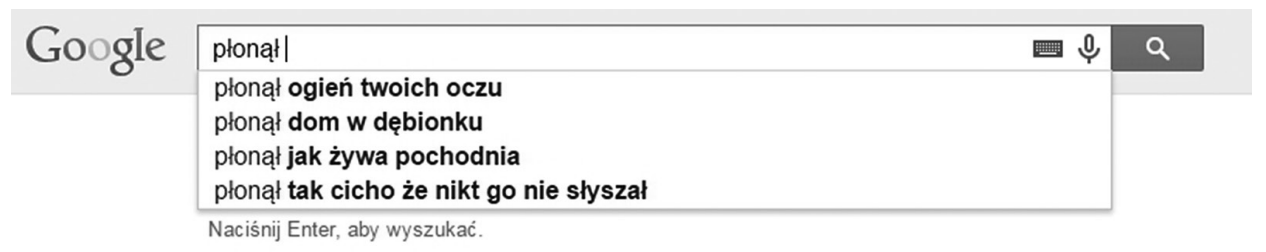

Rysunek 1. Przykładowy wiersz z Google [Firefox, 3 sierpnia 2015].

Utworzona tą drogą seria podpowiedzi daje serię wierszy (scil. linijek typograficznych) o mniejszej lub większej spoistości treściowo-asocjacyjnej, która spełnia wyznaczniki wiersza (kompozycji prozodyjnej) w rozumieniu Kulawi$\mathrm{ka}^{28}$ bądź - w wyjątkowych przypadkach — quasi-wersetu ${ }^{29}$ i, jako taka, może być również uznana za tekst poetycki ze względu na to, co o roli wspólnoty interpretacyjnej w percepcji wiersza pisał Stanley Fish, wedle którego sam ,akt rozpoznania jest [...] źródłem formalnych cech wiersza”, a zatem to ,pewnego rodzaju [kolektywnie konstruowana — ASM] uwaga powoduje wyłonienie się jakości poetyckich", nie zaś odwrotnie ${ }^{30}$. Analogicznie do Duchampowskich objets trouvés artefakt (tu: tekst) codziennego użytku staje się za sprawą działania artystycznego sztuką, a więc — jako obiekt artystyczny — podlega regułom rządzącym odbiorem komunikacji literackiej (tj. sztuki). Jonathan Culler mówi o ,pewnym rodzaju uwagi, który dałoby się określić jako literacką"31.

Powstałą w ten sposób kompozycję prozodyjną można, rzecz jasna, poddawać dalszym przekształceniom, dajmy na to rozbiciu wersów poprzez zastosowanie przerzutni (i tak się rzeczywiście czasami dzieje) lub/i korektorsko-typograficznym, czyli wstawić przecinki, wielkie litery, poprawić ewidentne błędy, niemniej dla istnienia samego tekstu nie jest to konieczne, a działania tego rodzaju należałoby już raczej traktować jako zabiegi transformacyjne na gotowym wytworze niż jako czynności zmierzające do powstania samego komunikatu. Oznacza to, że wiersze z Google to w istocie tekst taki, jaki zostaje wyświetlony w oknie przeglądarki.

27 Przykładowo wers trzeci z tekstu opublikowanego 1 lutego 2016: „Słońce błyszczy na wschodzie w chmur ognistych wianku / Słońce błyszczy na wschodzie / Błękitne słońce / Słońce nas błogosławiło i księżyc też tam był" [podkreślenie moje — ASM], http://wierszezGoogle. tumblr.com $/$ search $/ \mathrm{s} \% \mathrm{C} 5 \% 82 \mathrm{o} \% \mathrm{C} 5 \% 84 \mathrm{ce}+\mathrm{b} \% \mathrm{C} 5 \% 82$ yszczy [dostęp: 26.12 .2016 ].

28 A. Kulawik, Teoria wiersza, Kraków 1995, s. 64 n.

29 W. Sadowski, Wiersz litanijny, [w:] idem, Litania i poezja: Na materiale literatury polskiej od XI do XXI, Warszawa 2011, s. $111 \mathrm{n}$.

30 S. Fish, Jak rozpoznać wiersz, gdy się go widzi, przeł. A. Grzeliński, [w:] idem, Interpretacja, retoryka, polityka. Eseje wybrane, red. A. Szahaj, wyd. 2, Kraków 2008, s. 85.

31 J. Culler, Teoria literatury. Bardzo krótkie wprowadzenie, przeł. M. Bassaj, Warszawa 1998, s. 35 . 


\section{Relacje tekstualne, które budują (?) tekst}

Co zatem powiedzieć można o samym tekście? Z perspektywy teorii wiersza tekst składa się z czterech linijek-segmentów wyodrębnionych graficznie i prozodycznie (czyli wersów) będących syntagmami i opartych na anaforze, a zatem nieposiadających żadnych — poza wymienioną już anaforą — wykładników spójności logiczno-semantycznej. Jest ona nadawana głównie za sprawą uporządkowania tekstu w wiersz, tj. w wyniku wertykalnego następstwa kolejnych wersów, a zarazem wynika z faktu implicite przyjętego założenia, że ów ciąg znaków jest wierszem-utworem, czyli po prostu tekstem i, jako taki, posiada moc teleologicznego scalania swych elementów. A zatem, jeśli jest to spójny komunikat, to z czego on się — w sensie językowym, nie prozodyjnym — składa? Jak łatwo sprawdzić, pierwsza linijka wiersza o incipicie „płonął ogień twoich oczu” to tytuł książki Tracy Chevalier wydanej w Polsce w roku 2008, drugi odnosi się najprawdopodobniej do (błędnie wpisanego?) tytułu notatki prasowej, trzeci zaczerpnięto chyba z piosenki Edyty Bartosiewicz bądź z informacji o akcie samospalenia lub pożarze samochodu, ostatni zaś to przywołany dosłownie tytuł artykułu z „Gazety Wyborczej" (2012). Już na tym etapie analizy widzimy więc, że Google Poems z samej swej natury posiadają zdolność do akumulacji rozmaitych intertekstualnych śladów, a samo ich istnienie jest możliwe tylko o tyle, o ile dostępne są hipoteksty ${ }^{32}$. Hipotekstem może być przy tym tekst literacki (na przykład cytat z Sonetów odeskich Adama Mickiewicza czy, jak w drugim — podkreślonym przeze mnie — wersie z poniższego utworu, fragment Olifanta autorstwa Marcina Świetlickiego):

Zobaczyłem cię w remizie, wtedy chyba padał deszcz

Zobaczyłem światło, więc przyszedłem. Zadzwoniłem i otworzyłaś

Zobaczyłem zjednoczony naród

Zobaczyłem twarz diabła ${ }^{33}$

lub tekst popularnej piosenki, artykułu gazetowego czy choćby anonimowa (ale dobrze pozycjonowana) wypowiedź internauty:

po cóż jechać do turcji

po cóż komplikować

po cóż ci kochanie wiedzieć że do lasu idę spać

po có $\dot{z}^{34}$

czy wręcz „,pusta” fraza generująca (choćby „po cóż” z ostatniego wiersza powyższego tekstu). Ważne jedynie, by był on podany verbatim, czyli w doskonale identycznej formie, z jaką mamy do czynienia w źródle.

32 Por. G. Genette, Palimpsesty. Literatura drugiego stopnia, przeł. T. Stróżyński, A. Milecki, Gdańsk 2014.

33 http://wierszezgoogle.tumblr.com/image/54918129488 [dostęp: 22.12.2016].

$34 \mathrm{http} / / /$ wierszezgoogle.tumblr.com/post/132145428386/po-c\%C3\%B3\%C5\%BC-jecha\% $\%$ C4\% 87-do-turcji-po-c\%C3\%B3\%C5\%BC-komplikowa\%C4\%87-po [dostęp: 22.12.2016]. 
Często, jak w przykładzie trzecim, zidentyfikowanie wszystkich hipotekstów jest trudne: „po cóż jechać do turcji” (pisownia oryginalna) odsyła do twórczości Pawlikowskiej-Jasnorzewskiej ${ }^{35}$, ale też do artykułu naukowego z „Tekstów Drugich"36, kilku podróżniczych blogów oraz książki o losach Polaków w tymże kraju; czy wręcz niemożliwe - jak choćby w przypadku fraz typu: „widziałem jak żona mnie zdradza”, ,widziałem jezusa” (pisownia oryginalna) ${ }^{37}$ itp., dla których niemożliwością jest przypisanie jakiejkolwiek jednostkowej atrybucji, gdyż są to frazy funkcjonujące $w$ niezliczonej liczbie wypowiedzi anonimowych użytkowników polszczyzny. Dobrze ilustruje to wiersz:

nie mogę ci wiele dać

nie mogę przestać o tobie myśleć

nie mogę usunąć pliku ${ }^{38}$,

w którym od fragmentu popularnej kompozycji „przechodzimy”, poprzez anonimową, wyzbytą ze znaczenia pierwotnego wypowiedź, która nie ma teraz żadnego kontekstu - nie posiada autorstwa, nie ma nadawcy i odbiorcy, a więc całego owego hic et nunc, które konstytuuje znaczenie w komunikacji - do problemu związanego z obsługą komputera, co daje w efekcie interesujący obraz miłości w erze technologii cyfrowych, kiedy to zapisany na dysku plik, którego nie można się pozbyć, staje się znakiem nieszczęśliwej miłości.

Każdy pojedynczy wers jest z zasady intertekstualny, ale intertekstualności nie można uznać za zasadę generującą wers lub tekst. Jest ona wytwarzana niejako „przy okazji” i na płaszczyźnie semantycznej nie niesie tak naprawdę żadnej treści. Mówiąc innymi słowy: to, za sprawą czego budowany jest komunikat (uprzednio istniejące wypowiedzi), przestaje być użyteczne w momencie, gdy stanie się elementem wiersza z Google. Można powiedzieć, że jest to forma intertekstu, wszelako bez jego treści, substancji.

Intertekstualność, jako swoista zdolność do wytwarzania i podtrzymywania semantycznie istotnych relacji pomiędzy dwoma tekstami, nie dotyczy przy tym wersyfikacji ${ }^{39}$, gdyż nie odnosi się do parametrów wersu (w przeważającej mierze hipoteksty nie są w ogóle wierszami); nie ma również obligatoryjnego charakteru $^{40}$ — nie istnieje potrzeba identyfikacji hipotekstów, a sposób lektury zakłada wręcz ich nieznajomość: rozpoznanie jednej z linijek jako tytułu wiersza Pawlikowskiej-Jasnorzewskiej lub pracy Jarosińskiej niczego do lektury nie wno-

35 M. Pawlikowska-Jasnorzewska, Pocóż jechać do Turcji?, [w:] eadem, Wachlarz, Warszawa 1927, s. 11.

36 I. Jarosińska, Po cóż jechać do Turcji?, „Teksty Drugie” 2011, nr 5, s. 307-310.

$37 \mathrm{http} / / /$ wierszezGoogle.tumblr.com/search/widzia\%C5\%82em+jezusa [dostęp: 22.12.2016].

$38 \mathrm{http} / / /$ wierszezgoogle.tumblr.com/post/55359019406/nie-mog\%C4\%99-ci-wiele-da\%C4\% 87-nie-mog\%C4\%99-przesta\%C4\%87-o-tobie [dostęp: 22.12.2016].

39 Por. W. Sadowski, Wers jako cytat wersu we wspótczesnej poezji religijnej, „Zeszyty Naukowe KUL" 2005, z. 4, s. 25-38.

40 Por. R. Nycz, Tekstowy świat: poststrukturalizm a wiedza o literaturze, Kraków 2000, s. 85. 
si i (tak samo jak połączenie fragmentu z twórczości Świetlickiego, znanej piosenki ${ }^{41}$, filmu o katastrofie smoleńskiej i wypowiedzi księdza-egzorcysty) prędzej prowadzić może do konkluzji o nadmiarowości i chaotyczności treści w Sieci, niż być sygnałem czegokolwiek innego.

Czemu tak się dzieje? Najprostsze, zdroworozsądkowe wytłumaczenie brzmiałoby tak, że autor nie za bardzo rozumie, na czym owa intertekstualność polega, wybiera zatem teksty na chybił trafił, bez zastanowienia. Jak postaram się pokazać, ma ono wiele wspólnego z prawdą.

\section{Wyszukiwarka jako aktor w Sieci}

Jak zauważa jeden z autorów piszących dla czasopisma „Komputer Świat”, wyszukiwarki internetowe są „krwiobiegiem współczesnego internetu”, bez którego użytkownicy nie byliby w stanie efektywnie korzystać z zasobów ${ }^{42}$. Dzięki opcji wyszukiwania, by odszukać daną treść, wpisują oni frazy czy też słowa klucze (ang. keywords) będące na płaszczyźnie wyszukiwania odpowiednikami fraz generujących Google Poems. Służą one do przeszukiwania zasobów danych, przy czym użytkownicy mogą także wykorzystywać jakieś dodatkowe filtry wyszukiwania (typ pliku, na przykład obrazy, książki; czas dodania; język itd.) i w efekcie otrzymują podpowiedź w postaci linku URL, często z metaopisem ${ }^{43}$.

Warto w tym miejscu zauważyć też, że identyfikacja relacji intertekstualnej, czyli wyszukanie danego składnika, modyfikuje działanie algorytmu i czyni powrót do pierwotnego wyszukania w zasadzie niemożliwym.

Wiersze z Google nie są — pisze w cytowanym już tekście Sosnowska — działaniem na wskroś generatywnym. Opiera się to na wyborach dokonanych przez autorów. Pierwszym z nich jest wybór wyszukiwarki Google jako tej najczęściej używanej w Polsce. Już na tym poziomie zostaje podkreślona chęć opisania Polaków [...]. Należy [...] pamiętać, że to autorzy Wierszy z Google wpisują pierwszą część sentencji ${ }^{44}$.

John Battelle określa wyszukiwarkę Google wręcz jako „bazę naszych intencji"45, przy czym mamy tu na uwadze zarówno intencje jednostkowe (użytkownika danego urządzenia), jak i pojmowane w skali makro intencje wszystkich wyszukujących, zawarte w metawiedzy o wszystkich dotychczasowych wyszu-

41 Zob. http://bibliotekapiosenki.pl/utwory/Dzis_do_ciebie_przyjsc_nie_moge [dostęp: 22.07.2017].

42 [brak autora], Google pod lupq. Jak działaja wyszukiwarki internetowe?, http://www.komputerswiat.pl/jak-to-dziala/2012/03/jak-dzialaja-wyszukiwarki-internetowe.aspx [dostęp: 22.12.2016].

43 Ibidem. Por. Google Search, [hasło w:] Wikipedia, https://en.wikipedia.org/wiki/Google_ Search [dostęp: 25.07.2017].

44 J. Sosnowska, op. cit. [pisownia oryginalna - ASM].

45 J. Battelle, Szukaj. Jak Google i konkurencja wywołali biznesowa i kulturowa rewolucje, Warszawa 2006, cyt. za: M. Szpunar, Wyszukiwarka Google jako wspótczesny gatekeeper, „Studia Humanistyczne AGH” 2013, nr 12/2 , s. 112. 
kaniach (big data) oraz o każdym z nich z osobna, tworzących w sumie swego rodzaju biografię użytkownika umieszczoną w kontekście swoistej społecznej biografii danego społeczeństwa. Nie są one przy tym stałe, ale podlegają raczej ciągłej ewolucji. A skoro historia wyszukiwania modyfikuje otrzymywane podpowiedzi, oznacza to oczywiście, że będą one odmienne dla jednego użytkownika korzystającego z różnych urządzeń (na przykład komputer stacjonarny, laptop, tablet, smartfon) oraz tożsame dla odmiennych użytkowników w przypadku jednego urządzenia. Będą się one również różnić w zależności od czasu, kiedy wpisana zostanie dana fraza generująca, bo choć — jak się mówi — w Internecie nic nie znika, zmienia się jednak pozycjonowanie oraz napływają nowe źródła, co istotnie zmienia konfigurację podpowiedzi. Jak zauważa pisząca (z perspektywy jednostkowego użytkownika) o kategorii sprawczości w nowych mediach Aleksandra Kil:

Wyszukiwarka jest jednym z programów komputerowych, których używam najczęściej. Bez niej większość prób odnalezienia w Internecie czegokolwiek [...] byłaby błądzeniem po omacku. Zwykle World Wide Web odsłania się dla mnie na tyle, na ile pozwoli jej Google i, co ciekawe, zależy to także od tego, gdzie się znajduję i z jakiego urządzenia korzystam — wyniki wyszukiwania dostarczane przez program komputera dostępnego w uniwersyteckiej bibliotece mogą różnić się od tych wyświetlonych na ekranie mojego laptopa. Poza tym, Google oferuje mi skrojoną na miarę listę rezultatów (rozpoznawszy moje preferencje na podstawie tzw. historii online i plików cookies) i dobrze wie, w jakim miejscu świata przebywam (dzięki adresowi IP). W ten sposób przekonuję się, jak właściwie działa personalizacja wyszukiwarki i geolokalizacja, odczuwając jednocześnie, że nie tylko ja używam technologii, ale i ona wykorzystuje moją energię i dane, umożliwiając sprzedawanie ich reklamodawcom i doskonalenie parametrów programu. [Mam] świadomość, że w tych praktykach nie jestem jedyną instancją obdarzoną sprawczością, a proces wyszukiwania to $\mathrm{w}$ istocie splot mojej ciekawości i prywatności z polityką Google’a, internetowym marketingiem i technicznością medium - laptopem o aluminiowej obudowie, siecią Wi-Fi i słynnym już algorytmem napisanym przez Larry'ego Page'a i Sergeya Brina ${ }^{46}$.

Do tej obszernej charakterystyki dodać można jeszcze słowa samych autorów polskich Google Poems zamieszczone na stronie, wedle których są to: „dadaistyczne wiersze z Googlem i problemami Polaków [przyglądające się im — ASM] w krzywym zwierciadle searchów i ciasteczek"47.

Kil definiuje dwa rodzaje ludzkiej sprawczości: 1. wybór wyszukiwarki oraz 2. wybór początku ,,sentencji” (frazy generującej), a w konsekwencji nazywa użytkowników przeglądarki autorami. Do powyższych dodać należy również, że trzecim rodzajem sprawczości jest nasza aktywność w Sieci, której wynikiem są przechowywane w pamięci przeglądarki wyszukiwania i pliki cookies. Stanowisko takie tylko po części zgadza się ze stanem faktycznym. Załóżmy bowiem, że wiersze z Google generowane są na komputerze stacjonarnym umieszczonym w biurze jakiejś korporacji, w budynku uniwersyteckiej biblioteki lub podobnym, do którego dostęp ma kilka (lub nawet kilka tysięcy osób), ale pamięć podręczna, hi-

46 A. Kil, op. cit., s. 358.

47 http://wierszezGoogle.tumblr.com/about [dostęp: 19.12.2016]. 
storia wyszukiwania itp. nie jest na bieżąco usuwana. W tej sytuacji zbiór aktywności sieciowych rozmaitych — często bardzo odmiennych — jednostek ludzkich przypisanych do jednego adresu IP (bo ze sprzętu korzystać mogą i młoda kobieta, i starszy mężczyzna; i prawicowy nacjonalista, i lewicowiec-homoseksualista itd.), do jednego urządzenia tworzy przecież jedną, nierozerwalną całość i (tu i teraz) daje efekt w postaci tego właśnie, a nie innego wiersza z Google. To wszystko zaś wprzęgnięte zostaje w globalne zasoby Google Search i tym sposobem nasza jednostkowość i podmiotowość zupełnie zatraca się w nieskończonej masie działań. I choć nie jest to oczywiście sytuacja typowa — bo przecież urządzenia, z pomocą których przeszukujemy Sieć, stają się coraz bardziej spersonalizowane — to pozwala nam ona uświadomić sobie, co stanowi meritum całego zagadnienia: autorem jest tu raczej adres IP niż żywa osoba, raczej zasób i algorytm niż człowiek, w końcu — raczej Sieć niż jednostka.

Prześledźmy to na prostym przykładzie: dwa zamieszczone poniżej wiersze (rys. 2 i 3) zostały przeze mnie wygenerowane przy użyciu przeglądarki Chromium - której nie używam, a jedynie zainstalowałem ją na potrzeby niniejszej publikacji — w grudniu 2016 oraz w kwietniu 2017 r. przy użyciu tożsamej frazy generującej. Ponieważ, jak zaznaczam, nie używam tej przeglądarki do jakiejkolwiek aktywności sieciowej, oczywistym jest, że nie gromadzi ona żadnych moich wyszukiwań, nie jest wobec tego również źródłem wiedzy o mnie jako jednostce, nic nie mówi o mojej internetowej „biografii”. W efekcie zasadnym wydaje się założenie, że w tekstach niżej niczego o mnie nie ma, tj. są one w pewnym sensie transparentne, a wynik wyszukiwania jest „czysty” w tym znaczeniu, że brak tu interferencji pomiędzy moimi osobistymi preferencjami a globalnymi strategiami przeszukiwania zasobów. Skoro więc teksty są odmienne (a są), to nie dzieje się tak za sprawą mojej (,,autorskiej”) osoby, lecz ze względu na działanie samego procesu wyszukiwania, ze względu na to, co w międzyczasie działo się w Sieci ${ }^{48}$. Moja rola ograniczała się jedynie do uruchomienia przeglądarki i wpisania tej samej frazy generującej.
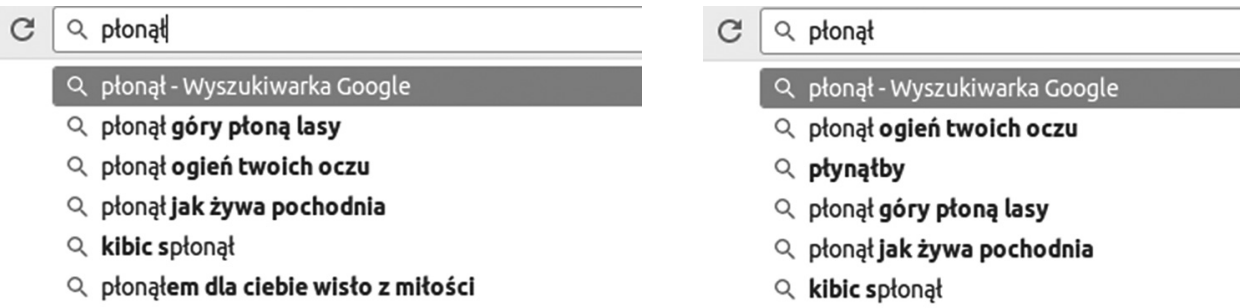

Rysunek 2 i 3. Wiersz z Google [Chromium, 28 grudnia 2016 i 16 kwietnia 2017].

48 Dodajmy, że nie importowałem żadnych ustawień z używanej przez mnie do codziennej pracy przeglądarki. 
Oczywiście wiersze te nie różnią się między sobą w jakiś istotny sposób. Jest to bardziej różnica kolejności wersów niż odmienności ich treści (nie licząc jednej linijki). Niemniej, pomijając nawet to, że następstwo wersów ma w poezji niebagatelne znaczenie ${ }^{49}$, łatwo zauważyć, jak ważna zmiana dokonała się między rokiem 2015 i dniem dzisiejszym — spójny w sumie i posiadający wręcz pewien „potencjał” liryczny wiersz przywołany na rysunku pierwszym zastąpiony został de facto grafomańskim bełkotem (o ile w tym przypadku w ogóle można takiego sformułowania użyć! ${ }^{50}$ ) obarczonym dodatkowo błędem (,płonął góry”!).

\section{Wnioski}

Nie przywołuję jednak tych wyszukań, by zastanawiać się, jak i dlaczego zmienia się treść Google Poems, lecz po to, by podważyć podzielany przez referowanych tu autorów pogląd głoszący, jakoby byli oni autorami tych tekstów. Sądzę, że w świetle omówionych przykładów utrzymanie takiego stanowiska jest wręcz niemożliwe, gdyż nie wypełniają one znamion autorstwa takich, jak to definiuje słownik i literatura przedmiotu ${ }^{51}$. A to oznacza, iż ludzie generujący wiersze z Google na swoich komputerach czy smartfonach nie są po prostu twórcami tych utworów, lecz jedynie działającymi w Sieci aktorami/aktantami (w rozumieniu koncepcji ANT Latoura ${ }^{52}$ ) czy też, jak to określił Jay David Bolter, ,procesorami informacji" 53 . Mamy tu więc do czynienia z koncepcją sieciowej sprawczości, gdzie rozmaici społeczni aktorzy (użytkownicy, wyszukiwarki i algorytmy) współdziałają z sobą w oparciu o zmienne zależności i relacje, w których wklepujący na swej klawiaturze litery człowiek jest tylko elementem (i to niespecjalnie istotnym), a już na pewno zupełnie nie jest on podobny do recyklingujących poetów w typie Barańczaka czy Różewicza — i to nie dlatego przecież, że efekt jest zupełnie innej jakości!

49 Por. choćby: L. Pszczołowska, Forma wierszowa a utwór liryczny, [w:] Poetyka, wybór i wstęp D. Ulicka, t. 1, Warszawa 2005, s. 20-21; A. Grabowski, Wiersz: forma i sens, Kraków 1999, s. $30-31$.

${ }^{50}$ Grafomania zakłada bowiem domyślnie osobę sprawczą, podmiot czynności twórczych: „grafomana”. Zob. M. Tramer, O litość dla grafomanów - wstępu stów kilka, [w:] Grafomania, red. M. Tramer, J. Zając, Katowice 2015, s. 7-9.

51 Autor, [hasło w:] Słownik języka polskiego, red. W. Doroszewski, Warszawa 2000, http:// doroszewski.pwn.pl/haslo/autor/ [dostęp: 2.03.2017]; A. Zawadzki, Autor. Podmiot literacki, [w:] Kulturowa teoria literatury. Gtówne pojęcia i problemy, red. M.P. Markowski, R. Nycz, wyd. 2, Kraków 2012, s. 233-235.

52 Mówiąc o koncepcji ANT, opieram się głównie na pracach: B. Domańska, B. Olsen, Wszyscy jesteśmy konstruktywistami, [w:] Rzeczy i ludzie. Humanistyka wobec materialności, red. J. Kowalewski, W. Piasek, M. Śliwa, Olsztyn 2008, s. 83-91; K. Arbiszewski, op. cit.

53 J. Bolter, Człowiek Turinga. Kultura zachodu wobec komputera, Warszawa 1990, s. 43, cyt. za: M. Szpunar, op. cit., s. 111. 
Efekt ten, jako wynik współpracy rozmaitych „sił twórczych”, nie jest przypisany — podobnie jak Ubu w ha! artowskim przekładzie lub poezja Świetlickiego zremiksowana przez Onaka — do jednostki (jednostek) rozumianej jako sprawca czy wytwórca dzieła/tekstu, ale stanowi wynik interakcji pomiędzy rozmaitymi aktantami, przy czym ludzie mają tu raczej znaczenie marginalne (to tak, jakby użytkowników języka uznawać za twórców słownika; lub odwrotnie - jakby to leksykografowie mogli być ,autorami” języka). Na tym owo niekreatywne prze-pisywnie literatury, języka czy wersyfikacji polega, że zasadniczy gest twórczy to tylko użycie zasobu. Tutaj jednak posuwamy się o krok dalej, bo ten, kto ów gest wykonuje, pozostaje niejako w zawieszeniu, gdy tymczasem samo działanie odbywa się poza nim - siłą sprawczą są inne podmioty. Ludzie-jednostki nie są po prostu sprawcami tekstu, a raczej pełnią $\mathrm{w}$ jego genezie rolę marginalną (właśnie niczym procesorzy Boltera ${ }^{54}$ ). I w oczywisty sposób odnosi się to tak do treści, która jest wynikiem swoistego kolażu oraz emergencji semantycznej nadbudowanej na znalezionych w zasobach frazach, jak do wersowania niebędącego $\mathrm{w}$ jakiejkolwiek mierze wynikiem autorskiej intencji ${ }^{55}$, lecz efektem bez-osobowego (w sensie ludzkim) procesu generowania tekstu z cząstek prozodyjnych (fraz) uprzednio wpisanych przez jakichś istniejących rzeczywiście ludzi, ale finalnie już nie przez nich, lecz przez wyszukiwarkę, znalezionych. $\mathrm{W}$ definicję wierszy z Google wpisuje się więc nie autorski gest arbitralnego użycia pauzy wersyfikacyjnej ${ }^{56}$, lecz mechanizm, jaki stoi za tym procesem — który generuje wersy i który nie należy już do sfery aktywności podmiotu-twórcy.

$\mathrm{O}$ ile owe frazy-wersy istnieją rzecz jasna uprzednio i są niejako „pobierane" w postaci gotowej, o tyle już zarówno ich wybór, jak i układ stanowią wynik sprawczego działania. Sądzę, że mamy tu do czynienia ze zjawiskiem analogicznym do wyboru wzorca metrycznego i jego aktualizacją w konkretnym tekście poezji metrycznej, choć oczywiście nieco odmiennym, bo tam schemat wersu i strofy wypełniany był treścią słowną, podczas gdy tutaj wypełniony już treścią słowną komponent jest wprzęgany w ponadwersową strukturę - niemniej działanie to nie jest domeną człowieka, a stworzonego przez niego programu, algorytmu oraz zasobów, z jakich tenże korzysta. Zasadniczą domeną człowieka pozostają jedynie skrajne etapy produkcji tekstu: wytworzenie hipotekstów (tekstów źródłowych, słownika) oraz najistotniejszy - wytworzenie tego, co Jakobson nazywał funkcją poetycką, scil. specyficznego nastawienia na komunikat, które sprawia, że tekst staje się poezją. I choć nie oznacza to automatycznie, jakoby wyszukiwarki, boty czy programy poetyckie — generator(z)y wierszy — już tworzyły (lub tworzyli) wiersze, które porównywać można z twórczością Barańczaka, Świetlickiego czy Różewicza, albo też będą je tworzyć w najbliższej przyszłości,

54 Ibidem.

55 Jak to w swej koncepcji za konstytutywne przyjmuje choćby Kulawik. Zob. idem, Wersologia, Kraków 1999, s. 38.

56 Ibidem. 
to istnienie Google Poetics pokazuje jasno, że sam podział tekstu na wersy, który dla nas ludzi jest jednym z wyznaczników poezji, poetyckości, autorskiej intencji stworzenia czegoś „naddatkowego” w komunikacji literackiej, już dziś niekoniecznie wynikać musi z jakieś naszej ludzkiej działalności, z czyjegoś geniuszu lub pomysłowości.

\section{Google poetics - issues of an authorship and agency within the view of a verse theory}

\section{Summary}

This article presents an attempt to explain the popular internet phenomenon called Wiersze $z$ Google (ang. Google Poetics), poems created by Google Searching engine - the most frequently used search engine on the World Wide Web. In author's opinion these poems are not created by humans only, but just an ,uncreative" effect of the poetic collaboration between the web browser, data bases, searching indexes and, last but not least, the users. Within the context of the theory of versification and some other intellectual backgrounds I try to show how these different agencies work together to create an unique poems based on peoples searchings, metadata and how words typed in the window of the browser become a poem-in-verses. 